\title{
Speciation of indium(III) chloro complexes in the solvent extraction process from chloride aqueous solutions to ionic liquids
}

OReceived 00th January 20xx Accepted 00th January 20xx

DOI: $10.1039 / x 0 x x 00000 x$

www.rsc.org/

\author{
Clio Deferm ${ }^{\mathrm{a}, \mathrm{b}}$, Bieke Onghena ${ }^{\mathrm{a}}$, Tom Vander Hoogerstraete ${ }^{\mathrm{a}}$, Dipanjan Banerjee ${ }^{\mathrm{d}}$, Jan Luyten ${ }^{\mathrm{b}}$, \\ Harald Oosterhof ${ }^{b}$, Jan Fransaer ${ }^{c}$ and Koen Binnemans ${ }^{* a}$
}

\section{Introduction}

Nowadays, indium finds applications in many electronic devices e.g. photovoltaics, flat screen TVs, laptops and mobile phones. Due to the increasing demand of indium for these applications as well as China's dominance in production (58\%), indium is considered a critical raw material by the European Commission. ${ }^{1}$ The high supply risk is further compounded by low substitutability and low recycling rates, resulting in higher prices and the need to increase the yearly production. ${ }^{2,3}$

Indium is a minor component in various lead, copper, iron and tin ores, but it is most commonly found in association with zinc ores such as sphalerite..$^{2,4,5}$ Since indium is accumulated in low concentrations in residues formed during the processing of these ores, it is often regarded as an impurity that increases production costs. ${ }^{6}$ Increasing the production of zinc could increase the availability of indium. However, it is economically unattractive to mine more zinc solely for the indium by-product, as global demand for zinc depends mainly on its use in the construction and automotive sectors. ${ }^{6}$ To keep up with the rising demand for high-tech applications, it is imperative to develop industrial processes for the successful recovery of indium from ore processing by-products and by recycling consumer goods. Hydrometallurgical separation methods, in particularly solvent extraction, are highly suitable for extracting

\footnotetext{
${ }^{a}$ KU Leuven, Department of Chemistry, Celestijnenlaan 200F, bus 2404, B-3001 Heverlee, Belgium. E-mail: Koen.Binnemans@kuleuven.be;

b Umicore, Group Research \& Development, Competence Area Recycling and Extraction Technologies, Watertorenstraat 33, B-2250 Olen, Belgium ${ }^{c} K U$ Leuven, Department of Materials Engineering, Kasteelpark Arenberg 44, bus 2450, B-3001 Heverlee, Belgium.

${ }^{d}$ Dutch-Belgian Beamline (DUBBLE), ESRF - The European Synchrotron, CS 40220, 38043 Grenoble Cedex 9, France

†Electronic Supplementary Information (ESI) available
}

indium from these sources. Solvent extraction is a commonly used method for the separation, purification and recovery of metals in process metallurgy due to its simplicity of equipment and operation.

Replacement of conventional molecular solvents in solvent extraction systems by ionic liquids could lead to inherently safer and more sustainable separation processes ${ }^{8-10}$, because of the negligible vapor pressure and low flammability of ionic liquids. ${ }^{11,12}$ lonic liquids (ILs) are solvents consisting completely of ions, mostly an organic cation and an inorganic anion, with melting points typically below $100{ }^{\circ} \mathrm{C} .{ }^{11,12}$ The physicochemical properties of ionic liquids can be tuned adequately for a given application. ${ }^{13}$ Two disadvantages, often observed for hydrophobic ionic liquids, are their toxicity in direct contact with the environment and their poor biodegradability. ${ }^{14-16}$ Water-immiscible ionic liquids have already been investigated as extractants for metals from aqueous solutions. ${ }^{10,17-21}$ Hydrophobic ionic liquids containing fluorinated anions, such as the hexafluorophosphate $\left(\mathrm{PF}_{6}{ }^{-}\right)$or the bis(trifluoromethylsulfonyl)imide $\left(\mathrm{Tf}_{2} \mathrm{~N}^{-}\right)$anion have to be avoided:22,23 Besides their high prices, hexafluorophosphate ionic liquids pose a risk due to hydrolysis and formation of hydrofluoric acid and bis(trifluoromethylsulfonyl)imide ionic liquids prove resistant to biological breakdown. ${ }^{14,24}$ From an environmental and economical point of view it is therefore advisable to use hydrophobic ionic liquids with long alkyl chains instead of fluorinated anions. ${ }^{22}$

Several metal extraction studies have been carried out using various non-fluorinated hydrophobic ionic liquids in diluted or undiluted form. These ionic liquids, such as Aliquat ${ }^{\circledR} 336^{25-27}$ and trihexyl(tetradecyl)phosphonium chloride (Cyphos ${ }^{\circledR}$ IL $101)^{28-33}$, are usually diluted in molecular solvents prior to use to tune the extraction efficiency and to decrease the viscosity of the organic phase, and thus to increase the mass transfer and 
kinetics. These studies mainly focused on the kinetics, the maximal loading and the extraction equilibrium, while structural information on the extracted complexes has been limited. The extraction mechanism metal transfer from the aqueous to the organic phase can be different for ionic liquids compared to molecular solvents. ${ }^{21,34,35}$ Metal ions can be extracted from the aqueous phase to the ionic liquid together with their counter ions by neutral extractants (L), either dissolved in a molecular diluent or not (= ion-pair mechanism or neutral mechanism, eq. 1 ).

$$
(\mathrm{nL})_{\mathrm{IL}}+\left(\mathrm{MX}_{\mathrm{z}}\right)_{\mathrm{Aq}} \rightleftharpoons\left(\left[\mathrm{MX}_{\mathrm{z}} \mathrm{L}_{\mathrm{n}}\right]\right)_{\mathrm{IL}}
$$

In some ionic liquids extraction can also occur via an ionexchange mechanism. This ion-exchange mechanism implies that ionic liquid cations, anions or protons (Eq. 2) from the extractant (L) are transferred from the organic phase to the aqueous phase during extraction of the metal ions. The ion-pair mechanism can also occur in combination with the ionexchange mechanism, depending on the conditions. ${ }^{21}$

$$
(\mathrm{nLH})_{\mathrm{IL}}+\left(\mathrm{M}^{\mathrm{n}+}\right)_{\mathrm{Aq}} \rightleftharpoons\left(\left[\mathrm{ML}_{\mathrm{n}}\right]\right)_{\mathrm{IL}}+\left(\mathrm{nH}^{+}\right)_{\mathrm{Aq}}
$$

Knowledge of the mechanism of a solvent extraction process based on ionic liquids is of importance because it allows tuning of conditions to ensure that no ionic liquid cations or anions are lost to the aqueous phase upon transfer of the metal ion to the ionic liquid phase. ${ }^{10,34-37}$ Also, knowledge of the speciation of metals in the aqueous phase is required to allow proper selection of extractants, since the extractability of metal ions depends strongly upon the structure of metal complexes in the aqueous phase. ${ }^{38}$ Moreover, the speciation of the metal ions in the aqueous and ionic liquid phase provides valuable information regarding the extraction mechanism.

Recently, we developed an efficient process for purifying indium by extraction from a chloride aqueous feed solution using the hydrophobic ionic liquids Cyphos ${ }^{\circledR}$ IL 101 and Aliquat ${ }^{\circledR} 336$ in undiluted form. ${ }^{39}$ Attention was paid to the loading capacity of the ionic liquid phase and the kinetics of the extraction process. In the present paper, the extraction mechanism was further corroborated and the speciation in the aqueous and ionic liquid phase was investigated. The extraction behavior of indium(III) from $\mathrm{HCl}$ solutions with undiluted Cyphos $\AA$ IL 101 and Aliquat ${ }^{\circledR} 336$ is determined. The structural properties of indium(III) chloro complexes in $\mathrm{HCl}$ solutions and in the ionic liquid phase are investigated as well.

\section{Experimental}

\section{Chemicals}

Trihexyl(tetradecyl)phosphonium chloride (Cyphos $®$ IL 101, purity $>97 \%$ ) was purchased from Cytec Industries Inc. (Niagara Falls, Ontario, Canada). Aliquat ${ }^{\circledR} 336$ (a commercial mixture of quaternary ammonium chlorides, with 88.2-90.6\% trioctylmethylammonium chloride), $\mathrm{InCl}_{3} \cdot 4 \mathrm{H}_{2} \mathrm{O}(97 \%)$ and $\mathrm{D}_{2} \mathrm{O}$ (99.9 atom \% D) were obtained from Sigma-Aldrich (Diegem,
Belgium). $\mathrm{CaCl}_{2} \cdot 2 \mathrm{H}_{2} \mathrm{O}$ (99.5+\%) was purchased from Chem-Lab (Zedelgem, Belgium) and $\ln \left(\mathrm{NO}_{3}\right)_{3} \cdot \mathrm{xH}_{2} \mathrm{O}$ (99.99\%) from Alfa Aesar (Karlsruhe, Germany). Silicone solution in isopropanol was obtained from SERVA Electrophoresis $\mathrm{GmbH}$ (Heidelberg, Germany) and the lanthanum standard solution (1000 $\left.\mathrm{g} \mathrm{L}^{-1}\right)$ from Merck (Overijse, Belgium). Hydrochloric acid solutions were prepared from $\mathrm{HCl}$ (37\%, Acros Organics, Geel, Belgium) and ultrapure water. Water was always of ultrapure quality, deionized to a resistivity of $>18.2 \mathrm{M} \Omega \mathrm{cm}$ with a Sartorius Arium Pro ultrapure water system. All chemicals were used as received, without further purification.

\section{Instrumentation and analysis methods}

After each extraction, the mixtures were centrifuged with a Eppendorf 5804 centrifuge. Metal concentrations were determined using a bench top total reflection X-ray fluorescence spectrometer (TXRF; Bruker S2 Picofox). For analysis of the aqueous phase by TXRF, an aliquot of the aqueous phase was mixed with a lanthanum internal standard solution and ultrapure water until a total volume of $1 \mathrm{~mL}$ was obtained. In order to create a hydrophobic surface, the quartz glass sample carriers were first treated with $20 \mu \mathrm{L}$ of a silicone solution in isopropanol and dried for $5 \mathrm{~min}$ in a hot air oven at $60{ }^{\circ} \mathrm{C}$. Afterxards, $5 \mu \mathrm{L}$ of the sample was added and the carriers were dried for $30 \mathrm{~min}$ at $60^{\circ} \mathrm{C}$. The metal concentrations in the aqueous phase were measured for $1000 \mathrm{~s}$. For the ionic liquid phase, the lanthanum internal standard was added to a small amount $(27 \mathrm{mg}$ ) of the ionic liquid phase and was further diluted with absolute ethanol until $1 \mathrm{~mL}$. The sample carrier pretreatment, the drying procedure and the measuring time were performed in the same way for the organic phase as described for the aqueous phase, but the sampling volume was reduced to $2 \mu \mathrm{L}$.

The viscosity of the organic phase was measured using a falling-ball type viscometer (Anton Paar, Lovis $2000 \mathrm{ME}$ ), densities were determined using a density meter with an oscillating U-tube sensor (Anton Paar, DMA $4500 \mathrm{M}$ ). A MettlerToledo DL39 coulometric Karl Fischer titrator was used with Hydranal ${ }^{\circledR}$ AG reagent to determine the water content of the ionic liquids.

Liquid-state ${ }^{115}$ In NMR spectra were recorded on a Bruker ${ }^{\circledast}$ Avance $^{\mathrm{TM}}$ II $600 \mathrm{MHz}$ Spectrometer, operating at $131.504 \mathrm{MHz}$ with a sweep width of $1187 \mathrm{ppm}$. The ${ }^{115}$ In NMR samples were measured at $60{ }^{\circ} \mathrm{C}$ without deuterated solvents present and with respect to an external reference of $0.1 \mathrm{M} \operatorname{In}\left(\mathrm{NO}_{3}\right)_{3} \cdot 6 \mathrm{H}_{2} \mathrm{O}$ in $\mathrm{D}_{2} \mathrm{O}$. All the samples were loaded into borosilicate NMR tubes (standard; $5 \mathrm{~mm}$ diameter), with the external reference sealed in a capillary tube. The system was irradiated at exactly the resonance frequency of the sample.

Extended X-ray Absorption Fine Structure (EXAFS) spectra of the indium K-edge (27941 eV) were collected at the DutchBelgian Beamline (DUBBLE, BM26A) at the European Synchrotron Radiation Facility (ESRF) in Grenoble (France). The energy of the X-ray beam was tuned by a double-crystal monochromator operating in fixed-exit mode using a $\mathrm{Si}(111)$ crystal pair. The measurements were done in transmission mode using $\mathrm{Ar} / \mathrm{He}$ gas-filled ionization chambers at ambient 
pressure. A brass sample holder with Kapton $\AA$ windows and a flexible polymeric spacer (VITON $®$ ) with a thickness of $2 \mathrm{~mm}$ was used as a sample holder for concentrated liquid samples $(>5$ $\left.\mathrm{g} \mathrm{L}^{-1}\right)$. Plastic cuvettes with a path length of $10 \mathrm{~mm}$ were used in case of less concentrated samples $\left(<5 \mathrm{~g} \mathrm{~L}^{-1}\right)$. Standard procedures were used for pre-edge subtraction and data normalization in order to isolate the EXAFS function $(\chi)$. The isolated EXAFS oscillations, obtained by subtraction of a smoothing spline using the Viper ${ }^{40}$ software, were $k^{3}$ - weighted and Fourier transformed over the $k$-range from 2.0 to 13.0 or $14.5 \AA^{-1}$ for the aqueous samples and from 2.0 to $18.9 \AA^{-1}$ for the ionic liquid samples using a Kaiser-Bessel window function. The data were fitted using the $a b$ initio code FEFF $7.0^{41}$, which was used to calculate the theoretical phase and amplitude functions that were subsequently used in the non-linear least-squares refinement of the experimental data. The EXAFS data were fitted in $R+\Delta(\AA)$ space between 0 and $5 \AA$. Estimated standard deviations are shown in parentheses and calculated by VIPER. $S_{0}$ was fixed for at 0.85 for the aqueous samples and at 1.045 for the ionic liquid samples. The value of 1.045 was obtained from fitting of the reference sample for ionic liquids, which was prepared by dissolving $\mathrm{InCl}_{3}$ in $\mathrm{Cyphos}^{\circledR} \mathrm{IL} 101$ in a 1:1 molar ratio and drying the mixture for 1 day on a Schlenk line at $60^{\circ} \mathrm{C}$.

\section{Solvent extraction}

The extraction experiments were performed using indium(III) chloride in an $\mathrm{HCl}$ acidified aqueous solution as feed and an undiluted ionic liquid as the organic phase. The ionic liquid was presaturated at $60{ }^{\circ} \mathrm{C}$ in a volume ratio of $4.5: 1$ with an aqueous $\mathrm{HCl}$ solution, of the same chloride concentration as the aqueous phase before extraction, to prevent excessive coextraction of ultrapure water and $\mathrm{HCl}$. Extractions were performed with equal volumes of ionic liquid and an acidified water phase ( $5 \mathrm{~mL}$ each) by intensive stirring with a magnetic stirring bar at $500 \mathrm{rpm}, 60 \mathrm{~min}$ at $60^{\circ} \mathrm{C}$. $\mathrm{HCl}$ was used as the chloride source. After the extraction, separation of the phases was assisted by centrifugation at $3500 \mathrm{rpm}$ for $15 \mathrm{~min}$. The speciation of indium in the aqueous and ionic liquid phase was determined as a function of the $\mathrm{HCl}$ concentration, ranging from 0 to $12 \mathrm{M}$, and the indium(III) concentration, ranging from 5 to $120 \mathrm{~g} \mathrm{~L}^{-1}$.

The viscosity of the ionic liquid phase after extraction was measured as a function of the indium(III) feed concentration at a hydrochloric concentration of $0.5 \mathrm{M} \mathrm{HCl}$ and with feed solution concentrations ranging from 5 to $120 \mathrm{~g} \mathrm{~L}^{-1}$ indium(III). The ionic liquid/indium(III) ratio at maximal loading of the ionic liquid was determined by extraction of indium(III) from aqueous solutions containing $50 \mathrm{~g} \mathrm{~L}^{-1}$ indium(III) and $0.5,6$ and $12 \mathrm{M} \mathrm{HCl}$, respectively, and by decreasing the volumes of the ionic liquid phase.

\section{Distribution ratio}

The distribution ratio $D$ of indium is defined as

$$
D_{\mathrm{In}}=\frac{[\mathrm{In}]_{\mathrm{IL}}}{[\operatorname{In}]_{\mathrm{aq}}}
$$

where $[\mathrm{In}]_{\mathrm{IL}}$ is the indium concentration in the ionic liquid and $[\mathrm{In}]_{\mathrm{aq}}$ is the indium concentration in the aqueous phase after extraction. If indium is strongly extracted to the ionic liquid phase $(\% E \geq 50 \%)$, only the remaining indium concentration in the aqueous phase was measured after extraction and eq. (3) can be rewritten as

$$
D_{\mathrm{In}}=\frac{[\mathrm{In}]_{0}-[\mathrm{In}]_{\mathrm{aq}}}{[\mathrm{In}]_{\mathrm{aq}}}
$$

where $[\mathrm{In}]_{0}$ is the initial indium concentration in the aqueous phase before extraction. The indium concentration in the ionic liquid phase was measured if indium was poorly extracted (\%E $<50 \%$ ), and eq. (3) becomes

$$
D_{\mathrm{In}}=\frac{[\mathrm{In}]_{\mathrm{IL}}}{[\operatorname{In}]_{0}-[\mathrm{In}]_{\mathrm{IL}}}
$$

The percentage extraction $(\% \mathrm{E})$ is defined as the amount of indium extracted to the ionic liquid phase over the initial amount of indium present in the aqueous phase:

$$
\% E=\frac{[\operatorname{In}]_{\mathrm{IL}}}{[\operatorname{In}]_{0}} \times 100 \%
$$

\section{Results and discussion}

\section{Indium(III) speciation in the aqueous phase}

In aqueous solutions, indium has the tendency to form a series of indium(III) chloride complexes in acid chloride media with a distinct distribution of the species $\left[\operatorname{lnCl}_{n}\left(\mathrm{H}_{2} \mathrm{O}\right)_{6-n}\right]^{3-n}$ $(0 \leq n \leq 6)$, depending on the chloride concentration. ${ }^{42-44}$

The first coordination sphere of the indium(III) complexes in aqueous $\mathrm{HCl}$ solutions was investigated by EXAFS. The background-corrected fine structures (EXAFS plots) and corresponding pseudo-radial distribution functions (PRDF plots) of aqueous indium(III) solutions as a function of the $\mathrm{HCl}$ concentration $\left([\mathrm{HCl}]=0,0.5,1,3,6,9,12 \mathrm{M} ;[\mathrm{In}]=5 \mathrm{~g} \mathrm{~L}^{-1}\right)$ are shown in the supporting information (Figs. +S1). Fig. 1 shows the EXAFS plot with the best signal-to-noise ratio and the corresponding PRDF plot attributed to a $0.5 \mathrm{M} \mathrm{HCl}$ solution loaded with $5 \mathrm{~g} \mathrm{~L}^{-1}$ of indium(III). The PRDF plots were obtained by Fourier transformation of the corresponding backgroundcorrected fine structures. The EXAFS data were fitted in $R+\Delta(\AA)$ space between 0 and $5 \AA$ to determine the accurate distances and coordination numbers $(N)$ in the different coordination spheres. The total number of coordinating oxygen or chlorine atoms was constrained to 6 . The fitting parameters are summarized in Table 1 . With increasing $\mathrm{HCl}$ concentration, the number of coordinating chlorine atoms increases while the number of neighbouring oxygen atoms decreases, indicating a change in speciation across the $\mathrm{HCl}$ concentration range. Moreover, it is observed that the interatomic distances increase as function of the $\mathrm{HCl}$ concentration. This is a consequence of the transition from a relative small positively charged indium(III) species to larger negatively charged indium(III) species: the dominant indium species changes from a $\left[\ln \left(\mathrm{H}_{2} \mathrm{O}\right)_{4} \mathrm{Cl}_{2}\right]^{+}$complex 
at low $\mathrm{HCl}$ concentrations $(<1 \mathrm{M} \mathrm{HCl})$ to a neutral $\left[\ln \left(\mathrm{H}_{2} \mathrm{O}\right)_{3} \mathrm{Cl}_{3}\right]$ complex between 1 and $6 \mathrm{M} \mathrm{HCl}$, followed by a single negatively charged $\left[\ln \left(\mathrm{H}_{2} \mathrm{O}\right)_{2} \mathrm{Cl}_{4}\right]^{-}$complex between 6 and $10 \mathrm{M} \mathrm{HCl}$ and ending with a double negatively charged $\left[\mathrm{In}\left(\mathrm{H}_{2} \mathrm{O}\right) \mathrm{Cl}_{5}\right]^{2-}$ complex at very high $\mathrm{HCl}$ concentrations $(10-12 \mathrm{M} \mathrm{HCl})$. Mark that at each $\mathrm{HCl}$ concentration, different indium species are present in the aqueous phase and that EXAFS is giving only averages.

There is convincing evidence for the formation of the species $\left[\ln \left(\mathrm{H}_{2} \mathrm{O}\right)_{5} \mathrm{Cl}\right]^{2+}, \quad\left[\ln \left(\mathrm{H}_{2} \mathrm{O}\right)_{4} \mathrm{Cl}_{2}\right]^{+}, \quad\left[\operatorname{lnCl}_{3}\left(\mathrm{H}_{2} \mathrm{O}\right)_{3}\right]$ and $\left[\ln \left(\mathrm{H}_{2} \mathrm{O}\right)_{2} \mathrm{Cl}_{4}\right]^{-}$in literature, although the fourth complex appears to be relatively unstable. ${ }^{42-47}$ Jarv et al. studied the Raman spectra of thirty-one solutions with a chloride-to-indium mole ratio from 0.48 to $15.9(0.30$ to $10.1 \mathrm{M} \mathrm{Cl}) .{ }^{44}$ The Raman spectra were adequately assigned to the presence of four species, $\left[\ln \left(\mathrm{H}_{2} \mathrm{O}\right)_{5} \mathrm{Cl}\right]^{2+}(0.30-3.87 \mathrm{M} \mathrm{Cl}),\left[\ln \left(\mathrm{H}_{2} \mathrm{O}\right)_{4} \mathrm{Cl}_{2}\right]^{+}(0.30-5.05 \mathrm{M} \mathrm{Cl})$, $\left[\ln \left(\mathrm{H}_{2} \mathrm{O}\right)_{3} \mathrm{Cl}_{3}\right](0.61-10.1 \mathrm{M} \mathrm{Cl})$ and $\left[\ln \left(\mathrm{H}_{2} \mathrm{O}\right)_{2} \mathrm{Cl}_{4}\right]^{-}(6.50-10.1 \mathrm{M}$ $\mathrm{Cl})$. The possible existence of $\left[\ln \left(\mathrm{H}_{2} \mathrm{O}\right) \mathrm{Cl}_{5}\right]^{2-}$ in aqueous solutions of very high chloride-to-indium mole ratio was not ruled out. These results are in agreement with our EXAFS results (Table 1). Hasson and Plane also investigated the indium speciation as a function of the chloride-to-indium mole ratio, 0.167 to 6.00 ( 0.335 to $2.01 \mathrm{M} \mathrm{Cl}$ ), by Raman spectroscopy. ${ }^{45}$ Three indium complexes were detected over the entire mole ratio range.
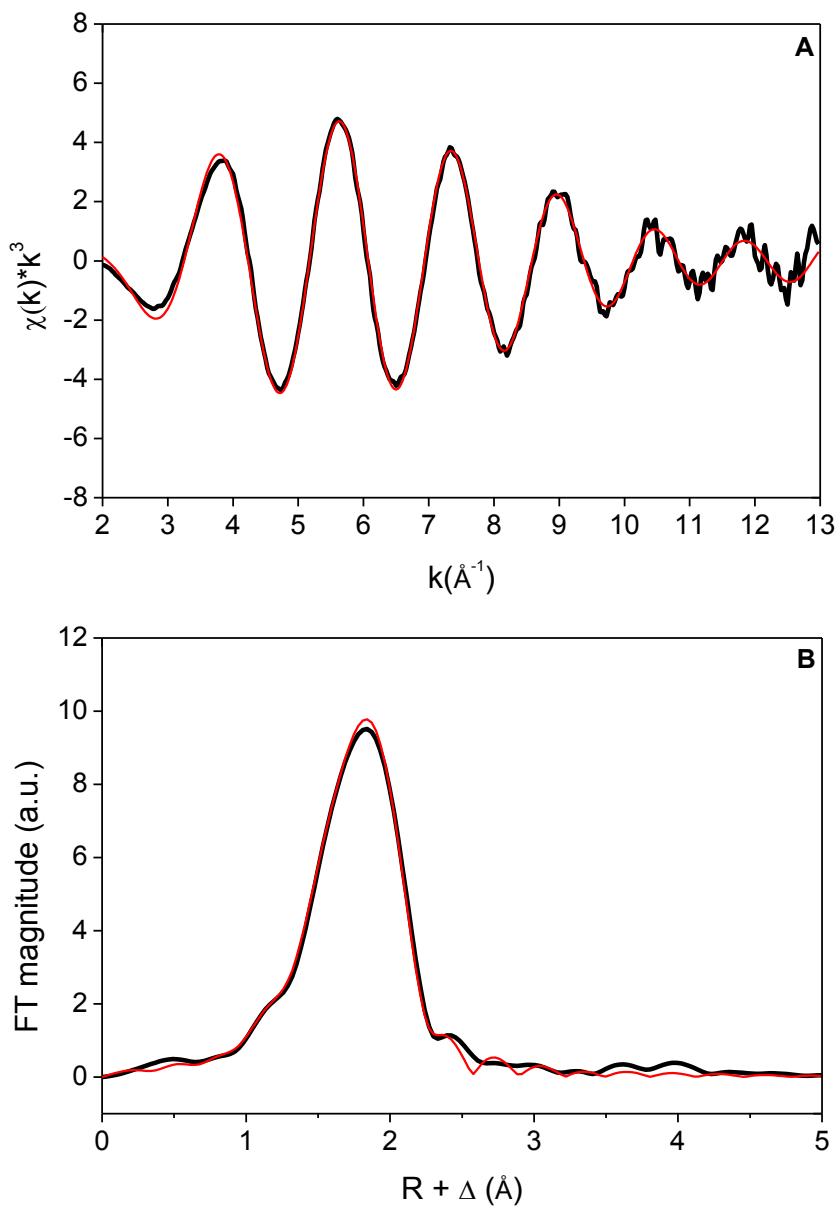

Fig. 1 Indium K-edge $\mathrm{k}_{3}$-weighted EXAFS spectrum (A) and the corresponding FT (B) for the indium(III) complex in a $0.5 \mathrm{M} \mathrm{HCl}$ solution containing $5 \mathrm{~g} \mathrm{~L}^{-1}$ indium. Experimental data (black) and theoretical fit (red) are shown.
Table 1 Fitting parameters for EXAFS used to analyse aqueous $\mathrm{HCl}$ solutions containing $5 \mathrm{~g} \mathrm{~L}^{-1}$ indium

\begin{tabular}{|c|c|c|c|}
\hline \multicolumn{4}{|c|}{ Chlorine } \\
\hline$[\mathrm{HCl}](\mathrm{M})$ & $\mathrm{N}^{\mathrm{a}}$ & $R(A ̊)^{b}$ & $\sigma^{2}\left(\AA^{2}\right)^{c}$ \\
\hline 0.0 & $1.5(9)$ & $2.417(2)$ & $0.003(1)$ \\
\hline 0.50 & $2.1(5)$ & $2.436(9)$ & $0.004(1)$ \\
\hline 1.0 & $2.5(9)$ & $2.443(14)$ & $0.004(2)$ \\
\hline 3.0 & $2.6(4)$ & $2.463(4)$ & $0.004(1)$ \\
\hline 6.0 & $3.4(2)$ & $2.485(4)$ & $0.004(1)$ \\
\hline 9.0 & $4.3(4)$ & $2.499(4)$ & $0.005(1)$ \\
\hline 12 & $5.0(1)$ & $2.500(1)$ & $0.006(2)$ \\
\hline \multicolumn{4}{|c|}{ Oxygen } \\
\hline$[\mathrm{HCl}](\mathrm{M})$ & $\mathrm{N}^{\mathrm{a}}$ & $R(A ̊)^{b}$ & $\sigma^{2}\left(\AA^{2}\right)^{c}$ \\
\hline 0.0 & $4.5(9)$ & $2.165(20)$ & $0.006(1)$ \\
\hline 0.50 & $3.9(5)$ & $2.180(13)$ & $0.006(1)$ \\
\hline 1.0 & $3.5(9)$ & $2.185(20)$ & $0.006(1)$ \\
\hline 3.0 & $3.5(4)$ & $2.227(6)$ & $0.007(2)$ \\
\hline 6.0 & $2.6(2)$ & $2.276(36)$ & $0.007(2)$ \\
\hline 9.0 & $1.7(4)$ & $2.318(14)$ & $0.007(1)$ \\
\hline 12 & $1.0(1)$ & $2.356(4)$ & $0.007(2)$ \\
\hline
\end{tabular}

${ }^{a} \mathrm{~N}$ is the number of coordinating atoms. ${ }^{b} \mathrm{R}$ is the interatomic distance. ${ }^{\mathrm{c}} \sigma^{2}$ is the Debye-Waller factor.

The $\left[\ln \left(\mathrm{H}_{2} \mathrm{O}\right)_{5} \mathrm{Cl}\right]^{2+}$ complex was the first complex identified by the authors. The two additional indium complexes were suggested to be $\left[\ln \left(\mathrm{H}_{2} \mathrm{O}\right)_{4} \mathrm{Cl}_{2}\right]^{+}$and $\left[\ln \left(\mathrm{H}_{2} \mathrm{O}\right)_{2} \mathrm{Cl}_{4}\right]^{-}$complexes but the authors do not eliminate the possibility of the existence of $\left[\ln \left(\mathrm{H}_{2} \mathrm{O}\right)_{3} \mathrm{Cl}_{3}\right]$. Schufle et al. showed that $\left[\ln \left(\mathrm{H}_{2} \mathrm{O}\right)_{2} \mathrm{Cl}_{4}\right]^{-}$is stable only at very high chloride concentrations ( $8 \mathrm{M}) .{ }^{46}$ Seward et al. found evidence for the presence of $\left[\ln \left(\mathrm{H}_{2} \mathrm{O}\right)_{2} \mathrm{Cl}_{4}\right]^{-}$in concentrated $\mathrm{HCl}$ solutions. ${ }^{47}$ The same conclusions were drawn from the EXAFS results showing that the single negatively charged $\left[\ln \left(\mathrm{H}_{2} \mathrm{O}\right)_{2} \mathrm{Cl}_{4}\right]^{-}$complex is dominant at $\mathrm{HCl}$ concentrations between 6 and $10 \mathrm{M} \mathrm{HCl}$. $\left[\ln \left(\mathrm{H}_{2} \mathrm{O}\right) \mathrm{Cl}_{5}\right]^{2-}$ and $\left[\mathrm{InCl}_{6}\right]^{3-}$ were not detected in Raman studies of the indium(III)chloride system at chloride concentrations as high as $2 \mathrm{M}$ (Hanson and Plane ${ }^{45}$ ) and $10 \mathrm{M}$ (Jarv et al. ${ }^{44}$ ). We were able to detect the $\left[\mathrm{In}\left(\mathrm{H}_{2} \mathrm{O}\right) \mathrm{Cl}_{5}\right]^{2-}$ complex at a $\mathrm{HCl}$ concentration of 12 M.

In this work, ${ }^{115}$ In NMR spectroscopy was used to the confirm the indium(III) speciation in the aqueous phase. Indium has two NMR-active isotopes, ${ }^{113} \mathrm{In}$ and ${ }^{115} \mathrm{In} .{ }^{115} \mathrm{In}$ has a larger receptivity than ${ }^{113} \mathrm{In}$ and is the preferred nucleus for NMR measurements. ${ }^{48,49}$ It is characterized by a high sensitivity for detection by NMR (Relative receptivity to ${ }^{1} \mathrm{H}=0.332$ ) ${ }^{49}$ It is a quadrupolar nucleus (spin I =9/2) with short relaxation times leading to broad NMR signals and a low resolution. ${ }^{48,50}$ However, the line width is very sensitive to the local symmetry around the indium nucleus due to its large quadrupole moment. ${ }^{49,51,52}$ Indium in a highly symmetric environment, e.g. $\left[\mathrm{InCl}_{4}\right]^{-},\left[\mathrm{InCl}_{6}\right]^{3-}$, exhibits narrower NMR lines than indium in a low symmetric environment, e.g. $\left[\mathrm{InCl}_{5}\right]^{2-}$. Failure to observe NMR lines of indium in an environment of low symmetry is not uncommon due to line broadening. ${ }^{48}$ 
${ }^{115}$ In NMR spectra of the aqueous phase before extraction were measured having various $\mathrm{HCl}$ concentrations to confirm the change in speciation across the $\mathrm{HCl}$ concentration range. The spectra as a function of the $\mathrm{HCl}$ concentration $([\mathrm{HCl}]=0.5$, $1,3,6,9,12 \mathrm{M} ;[\mathrm{In}]=5 \mathrm{~g} \mathrm{~L}^{-1}$ ) are shown in Fig. $+\mathrm{S} 2$. No definable difference in chemical shift was observed across the $\mathrm{HCl}$ concentration range (95-103 ppm) due to the very broad line width of the signals. These broad ${ }^{115} \mathrm{In}$ resonances are characteristic for the presence of $\left[\ln \left(\mathrm{H}_{2} \mathrm{O}\right)_{6-n} \mathrm{Cl}_{n}\right]^{3-n}$ mixed complexes of low symmetry. ${ }^{53-54}$

\section{Solvent extraction of indium(III)}

The distribution ratios of indium(III) $\left(D_{\mathrm{In}}\right)$, for the $\mathrm{HCl}-$ Cyphos $\AA \mathrm{IL} 101$ and $\mathrm{HCl}-$ Aliquat ${ }^{\circledR} 336$ systems at $60{ }^{\circ} \mathrm{C}$, measured as a function of the $\mathrm{HCl}$ concentration are shown in Fig. 2, reproduced from an earlier publication. ${ }^{39}$ In both systems, the $D_{\text {In }}$ increases at lower $\mathrm{HCl}$ concentrations; with a maximum $D_{\mathrm{In}}$ at around $5 \mathrm{M} \mathrm{HCl}$; followed by a decrease of $D_{\text {in }}$ at higher $\mathrm{HCl}$ concentrations. The bell-shaped curve of the distribution ratio is tentatively attributed to a change in speciation or stability of the indium complexes in the aqueous and/or in the ionic liquid phase. This change in speciation or stability of the indium(III) complexes is a consequence of the changing $\mathrm{HCl}$ concentration and water content in both phases, due to extraction of $\mathrm{HCl}$ and $\mathrm{H}_{2} \mathrm{O}$ towards the ionic liquid phase. Even though the extraction of $\mathrm{HCl}$ and $\mathrm{H}_{2} \mathrm{O}$ is expected to be small, the former can become significant at high $\mathrm{HCl}$ concentrations in the aqueous phase. ${ }^{55-57}$

To determine the stoichiometry of the indium(III) chloride complex extracted by the ionic liquid, maximal loading experiments were performed. Samples of the aqueous phase $(5 \mathrm{~mL})$ containing $50 \mathrm{~g} \mathrm{~L}^{-1}$ indium and various $\mathrm{HCl}$ concentrations were brought into contact with decreasing volumes of ionic liquid, until the point at which the ionic liquid was saturated with indium(III) ions and no free extractant molecules were left. The excess of metal ions remained in the aqueous phase. The concentrations of Cyphos ${ }^{\circledR}$ IL 101 (1.6 M) and Aliquat ${ }^{\circledR} 336(1.8 \mathrm{M})$ are constant in the undiluted form. If

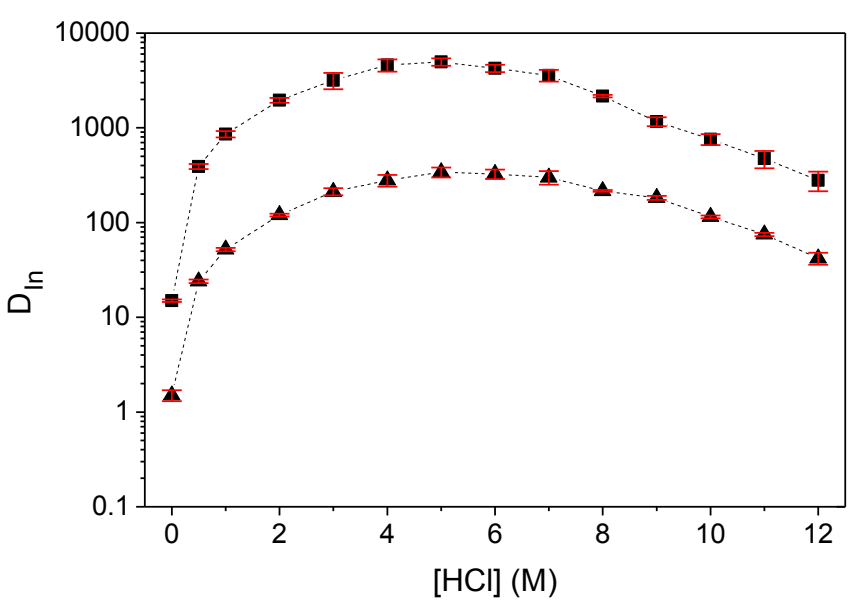

Fig. 2 Distribution ratios of indium(III) $\left(D_{I n}\right)$ as a function of $\mathrm{HCl}$ concentration for the $\mathrm{HCl}-$ Cyphos ${ }^{\circledR} \mathrm{IL} 101(\boldsymbol{\square})$ and $\mathrm{HCl}$-Aliquat ${ }^{\circledR} 336(\boldsymbol{A})$ systems at $60{ }^{\circ} \mathrm{C}$. The volume ratio of the aqueous to the organic phase is $1: 1$. Aqueous phase: initial indium(III) concentration $5 \mathrm{~g} \mathrm{~L}^{-1}$. Reproduced from Ref. [39].

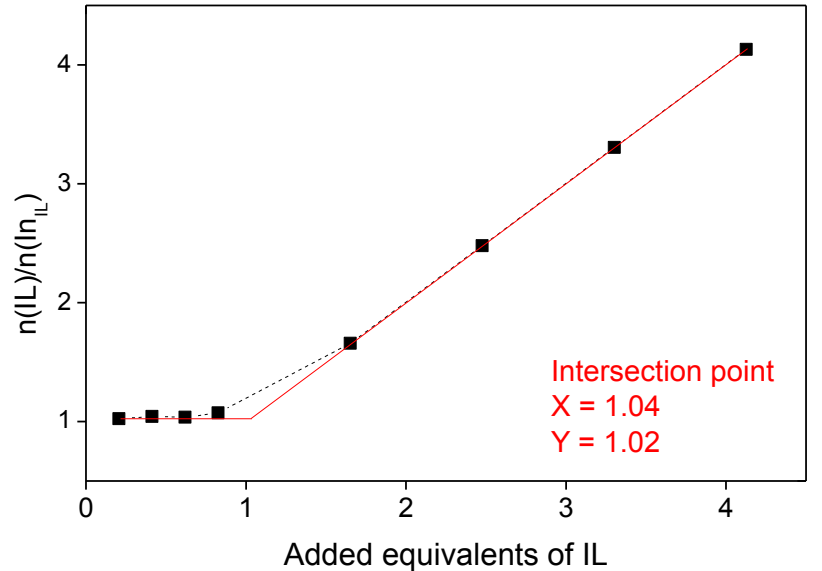

Fig. 3 Number of moles of IL (Cyphos ${ }^{\circledR}$ IL 101) over the number of moles of extracted indium $\left(n(I L) / n\left(I n_{L}\right)\right.$ ) as a function of the number of ionic liquid equivalents (Cyphos ${ }^{\circledR}$ IL 101) added, at constant initial metal concentrations of indium and $60^{\circ} \mathrm{C}$. Aqueous phase: initial indium(III) concentration $50 \mathrm{~g} \mathrm{~L}^{-1}$, initial $\mathrm{HCl}$ concentration $5 \mathrm{M}$.

the ionic liquid is present in an excess and the stability constant of the indium-extractant complex $(\beta)$ is larger than 100 under the same conditions, percentages extractions all above $99 \%$ were expected. High percentage extraction in combination with high stability constants means that no free ionic liquid will be present once all ionic liquid molecules are involved in the extraction process. From Fig. 3 and +53 , it is evident that when the number of ionic liquid equivalents added to the system was decreased below one, the molar ratio of the ionic liquid over indium extracted in the ionic liquid phase remained almost constant at a value of one, or $n(I L) / n\left(\operatorname{In}_{\mathrm{LL}}\right)=1$. This suggests that each indium(III) ion is extracted by one molecule of the ionic liquid, whether it is Cyphos $\AA$ IL 101 or Aliquat $\AA 336$, at maximal loading of the ionic liquid phase. The theoretical indium(III) loading capacity of $184 \mathrm{~g} \mathrm{~L}^{-1}$ for Cyphos ${ }^{\circledR} \mathrm{IL} 101$ and $207 \mathrm{~g} \mathrm{~L}^{-1}$ for Aliquat ${ }^{\circledR} 336$.

A gradual increase in the viscosity of the ionic liquid phase was observed when it was loaded with higher indium(III) concentrations (Fig. 4). This indicates that the chloroindate(III) anion formed in the ionic liquid phase during extraction has probably the same charge as the chloride anion in the pure ionic liquid, i.e. that the $\left[\mathrm{InCl}_{4}\right]^{-}$anion is formed rather than the higher charged species such as $\left[\mathrm{InCl}_{5}\right]^{2-}$ or $\left[\mathrm{InCl}_{6}\right]^{3-}$. Higher charged species are known to lead to a sharp increase of the viscosity at higher loadings as a consequence of the stronger intermolecular interactions between the cation and the anion of the ionic liquid. ${ }^{58-60}$ In contrast with the extraction of indium(III) with Cyphos ${ }^{\circledR}$ IL 101 and Aliquat ${ }^{\circledR} 336$, the viscosity of the ionic liquid phase increased significantly when the metal concentration in the organic phase was increased for the extraction of cobalt(II) with Cyphos ${ }^{\circledR}$ IL $101^{60}$, samarium(III) with Cyphos ${ }^{\circledR}$ IL 101 in nitrate form ${ }^{58}$ and neodymium(III) with Aliquat ${ }^{\circledR} 336$ in nitrate form ${ }^{61}$. Therefore, it can be assumed that the indium(III) complex in the ionic liquid phase contains only one cation and an anion with a -1 electric charge. 


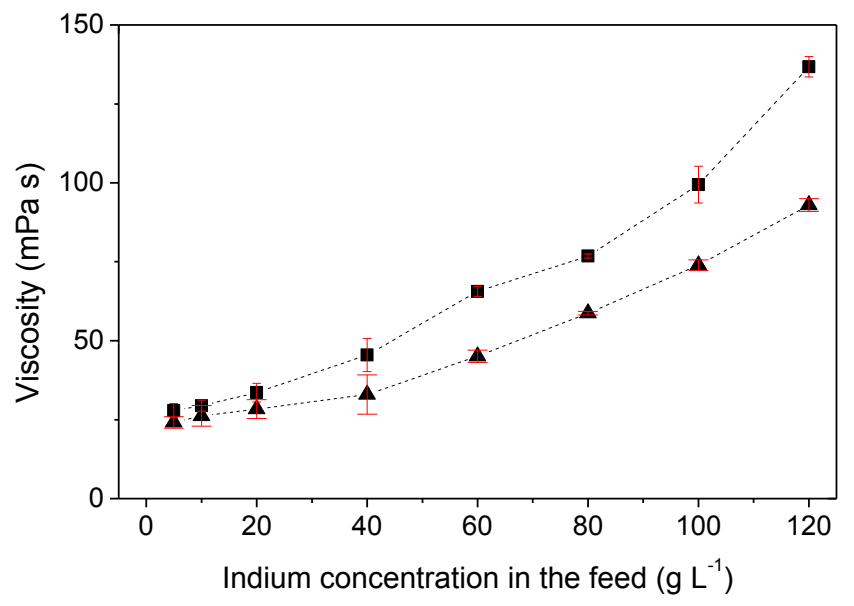

Fig. 4 Viscosity of the ionic liquid phase at equilibrium as function of the indium(III)

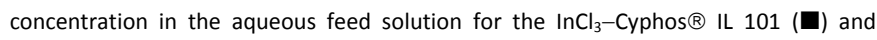
$\mathrm{InCl}_{3}-$ Aliquat ${ }^{\circledR} 336(\boldsymbol{\Delta})$ systems at $60^{\circ} \mathrm{C}$. The volume ratio of the aqueous to the organic phase is $1: 1$. Aqueous phase: initial $\mathrm{HCl}$ concentration $0.5 \mathrm{M}$.

\section{Indium(III) speciation in the ionic liquid phase}

The first coordination sphere of the extracted indium(III) complexes was investigated by EXAFS. The speciation of $\mathrm{InCl}_{3}$ in several ionic liquids had already been investigated by several researchers. ${ }^{62-64}$ The usually accepted speciation for the system indium chloride/ionic liquid (water free) in 1:1 molar ratio, is the tetrahedral $\left[\mathrm{InCl}_{4}\right]^{-}$complex. ${ }^{62-64}$ This complex was used to determine $S_{0}$ (amplitude reduction factor), 1.045, in similar extracted complexes. $\mathrm{InCl}_{3}$ dissolved in a 1:1 molar ratio in Cyphos ${ }^{\circledR}$ IL 101 was used as a reference sample. It was not possible to dissolve $\mathrm{InCl}_{3}$ in the same molar ratio in Aliquat $\circledast$ 336. The identical shape of the distribution ratios as a function of the $\mathrm{HCl}$ concentration of the $\mathrm{InCl}_{3}-$ Cyphos ${ }^{\circledR} \mathrm{IL} 101$ and $\mathrm{InCl}_{3}$-Aliquat ${ }^{\circledR} 336$ system (Fig. 2 ) suggests that the mechanism of indium(III) extraction is the same, and that the speciation of indium(III) in these two ionic liquids is very similar. Therefore, EXAFS measurements were only executed on the $\mathrm{InCl}_{3}$-Aliquat ${ }^{\circledR} 336$ system. The EXAFS plots and corresponding PRDF plots of Aliquat ${ }^{\circledR} 336$ as a function of the $\mathrm{HCl}$ concentration $\left([\mathrm{HCl}]=0.5,3,6,12 \mathrm{M} ;[\mathrm{In}]=5 \mathrm{~g} \mathrm{~L}^{-1}\right)$ and indium concentration $\left([\mathrm{In}]=5,60,120 \mathrm{~g} \mathrm{~L}^{-1} ;[\mathrm{HCl}]=0.5 \mathrm{M}\right)$ are shown in the supporting information (Figs. +S4 and +S5). Fig. 5 shows the EXAFS plot with the best signal-to-noise ratio and the corresponding PRDF plot attributed to Aliquat ${ }^{\circledR} 336$ loaded with $120 \mathrm{~g} \mathrm{~L}^{-1}$ of indium(III). The PRDF plots were obtained by Fourier transformation of the corresponding backgroundcorrected fine structures. The EXAFS data were fitted in $\mathrm{R}+\Delta(\AA \AA)$ space between 0 and $5 \AA$ with $\mathrm{S}_{0}$ fixed at 1.045. The background-corrected fine structure did not change with increasing $\mathrm{HCl}$ or indium concentration, suggesting that the speciation of indium(III) in the ionic liquid is invariant. Curve fitting was performed to determine the accurate distances and coordination numbers $(\mathrm{CN})$ of the different coordination spheres. The fitting parameters obtained for the $\mathrm{InCl}_{3}-$ Aliquat ${ }^{\circledR}$ 336 system are summarized in Table 2 . In all the systems, the $\mathrm{CN}$ value is about 4 and a constant $\mathrm{In}-\mathrm{Cl}$ bond length of 2.365-2.376 ^ was found. These parameters are in good agreement with those in the tetrahedral $\left[\mathrm{InCl}_{4}\right]^{-}$complex.
Similar results were obtained for the solvent extraction of indium(III) from an aqueous $\mathrm{HCl}$ solution with tri- $n$-octyl amine (TOA) by Narita et al. ${ }^{38}$ The tetrahedral $\left[\mathrm{InCl}_{4}\right]^{-}$complex in the ionic liquid phase was found to be independent of the $\mathrm{HCl}$ concentration in the aqueous phase.
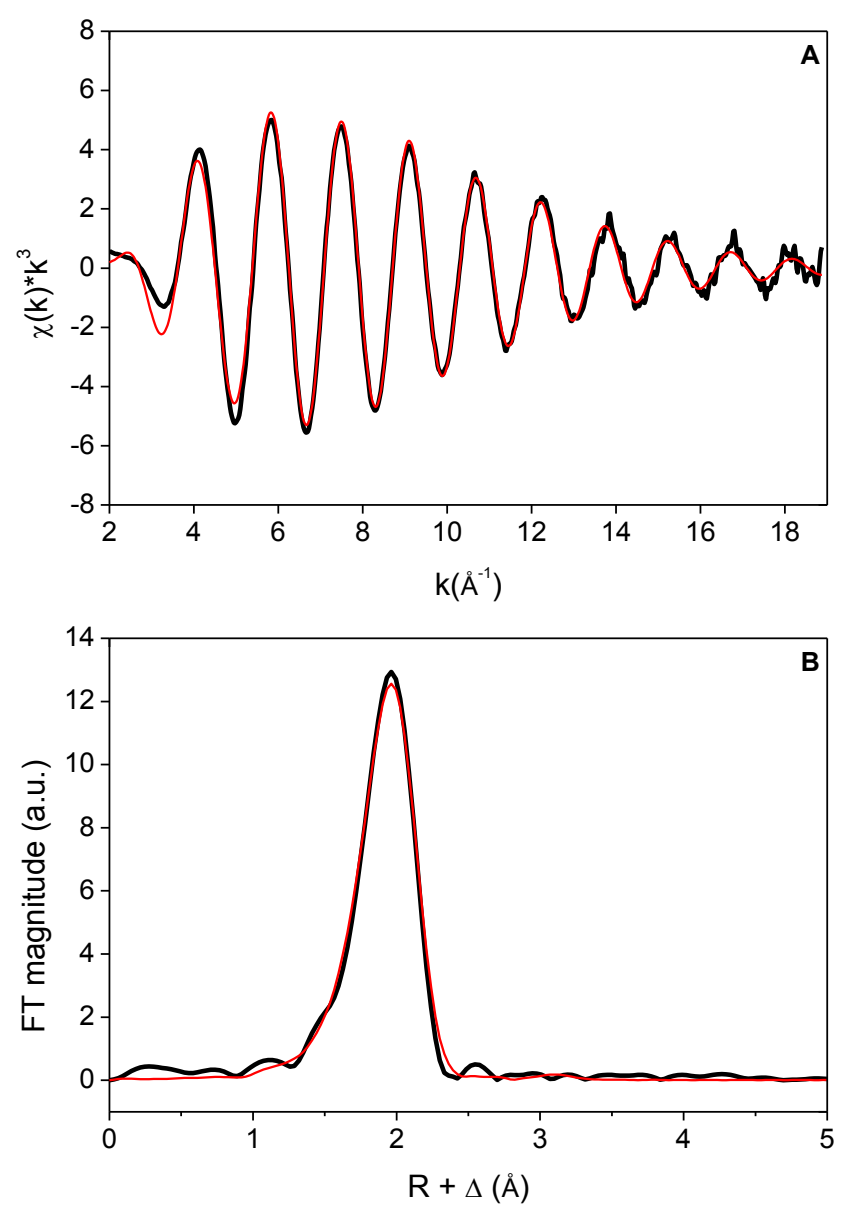

Fig. 5 Indium K-edge $k^{3}$-weighted EXAFS spectrum (A) and the corresponding FT (B) for the indium(III) complex in Aliquat ${ }^{\circledR} 336$. IL phase obtained after extraction containing $120 \mathrm{~g} \mathrm{~L}^{-1} \mathrm{In}$. Experimental data (black) and theoretical fit (red) are shown.

Table 2 Fitting parameters for EXAFS used to analyse the Aliquat ${ }^{\circledR} 336-\mathrm{InCl}_{3}$ system

\begin{tabular}{ccccc}
\hline$[\mathrm{HCl}](\mathrm{M})$ & {$[\mathrm{In}]\left(\mathrm{g} \mathrm{L}^{-1}\right)$} & $\mathrm{N}^{\mathrm{b}}$ & $\mathrm{R}(\AA)^{\mathrm{c}}$ & $\sigma^{2}\left(\AA^{2}\right)^{\mathrm{d}}$ \\
\hline 0.50 & 5.00 & $3.7(6)$ & $2.370(2)$ & $0.005(2)$ \\
3.0 & 5.00 & $3.7(1)$ & $2.366(2)$ & $0.004(1)$ \\
6.0 & 5.00 & $3.9(1)$ & $2.365(1)$ & $0.004(1)$ \\
9.0 & 5.00 & $3.9(1)$ & $2.365(1)$ & $0.004(1)$ \\
12 & 5.00 & $3.8(1)$ & $2.375(3)$ & $0.006(1)$ \\
0.50 & 60.0 & $3.7(1)$ & $2.376(2)$ & $0.005(1)$ \\
0.50 & 120 & $4.0(1)$ & $2.364(2)$ & $0.004(1)$ \\
$\operatorname{InCl}$ in Cyphos $^{\circledR}$ IL $101(1: 1$ molar ratio) & & $4.0(1)$ & $2.364(2)$ & $0.004(1)$
\end{tabular}

${ }^{\mathrm{a}} \mathrm{nCl}_{3}$ dissolved in $\mathrm{Cyphos}^{\circledR} \mathrm{IL} 101$ in a 1:1 molar ratio is the reference sample. ${ }^{\mathrm{b}} \mathrm{N}$ is the number of coordinating chlorine atoms. ${ }^{C} R$ is the interatomic distance. ${ }^{d} \sigma^{2}$ is the Debye-Waller factor.

${ }^{115}$ In NMR spectroscopy was also used to the determine the composition of the extracted indium(III) complexes. ${ }^{115}$ In NMR 
spectra of the ionic liquid phase after extraction were measured having varying indium(III) and $\mathrm{HCl}$ concentrations. A typical NMR spectrum is shown in Fig. 6. As expected from a quadrupolar nucleus, broad NMR signals were observed. The external reference $\left(0.1 \mathrm{M} \ln \left(\mathrm{NO}_{3}\right)_{3} \cdot 6 \mathrm{H}_{2} \mathrm{O}\right.$ in $\left.\mathrm{D}_{2} \mathrm{O}\right)$ is represented by the signal at $0 \mathrm{ppm}$. The signal at $401 \mathrm{ppm}$ represents the $\mathrm{InCl}_{3}-\mathrm{Cyphos}^{\circledR} \mathrm{IL} 101$ system. The chemical shifts found were compared to literature data for chloroindate(III) anions in molecular solvents (Table 3 ). The ${ }^{115}$ In NMR spectra of the $\mathrm{InCl}_{3}-\mathrm{IL}$ systems were acquired at $60^{\circ} \mathrm{C}$ in order to reduce the viscosity and obtain narrower signals. The spectra as a function of the $\mathrm{HCl}$ concentration $([\mathrm{HCl}]=0.5,1,3,6,9,12 \mathrm{M}$; $[\mathrm{In}]=5$ $\left.\mathrm{g} \mathrm{L}^{-1}\right)$ and indium concentration $([\mathrm{HCl}]=0.5 ;[\mathrm{In}]=5,10,20,40$, $60,80,100,120 \mathrm{~g} \mathrm{~L}^{-1}$ ) for the $\operatorname{InCl}_{3}-$ Cyphos ${ }^{\circledR} \mathrm{IL} 101$ and $\mathrm{InCl}_{3}$-Aliquat ${ }^{\circledR} 336$ system are shown in Figs. +S5 and +S6. Chemical shifts of the signals are lying in the same range as observed for tetrachloroindate anions, $[\mathrm{InCl}]_{4}^{-}$in molecular solvents. This suggests that the majority of indium exists in the

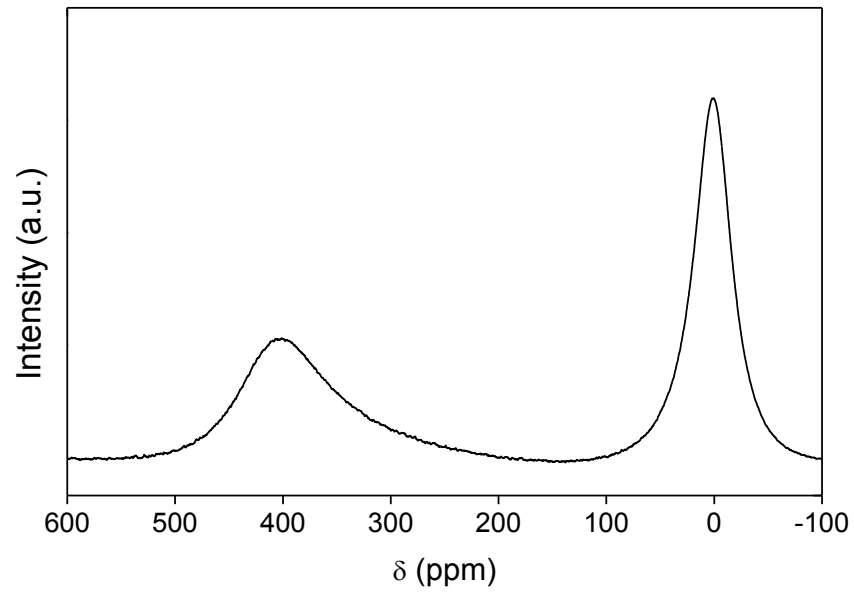

Fig. $6{ }^{115}$ In NMR spectra of the $\operatorname{InCl}_{3}-\mathrm{Cyphos} \otimes$ IL 101 system at $60^{\circ} \mathrm{C}$ obtained afte extraction with $5 \mathrm{~g} \mathrm{~L}^{-1}$ indium(III) and $0.5 \mathrm{M} \mathrm{HCl}$.

Table $3^{115}$ In NMR data measured for the $\operatorname{InCl}_{3}-$ Cyphos ${ }^{\circledR}$ IL 101 and $\operatorname{InCl}_{3}-$ Aliquat ${ }^{\circledR} 336$ system compared with the literature data for chloroindate(III) anions in molecular solvents $48,50-52,53,54,62,63$ measured with respect to an external reference $\ln \left(\mathrm{NO}_{3}\right)_{3} \bullet 6 \mathrm{H}_{2} \mathrm{O}$ in $\mathrm{D}_{2} \mathrm{O}$.

\begin{tabular}{|c|c|}
\hline System & $\delta(\mathrm{ppm})$ \\
\hline $\operatorname{In}(\mathrm{III})$ in Cyphos ${ }^{\circledR}$ IL 101; [In] $=5-120 \mathrm{~g} \mathrm{~L}^{-1},[\mathrm{HCl}]=0.5 \mathrm{M}$ & $390-420$ \\
\hline In(III) in Aliquat ${ }^{\circledR} 336 ;[\mathrm{In}]=5-120 \mathrm{~g} \mathrm{~L}^{-1},[\mathrm{HCl}]=0.5 \mathrm{M}$ & $337-396$ \\
\hline $\operatorname{In}(\mathrm{III})$ in Cyphos ${ }^{\circledR}$ IL $101 ;[\mathrm{In}]=5 \mathrm{~g} \mathrm{~L}^{-1},[\mathrm{HCl}]=0.5-12 \mathrm{M}$ & $401-457$ \\
\hline In $\left(\right.$ III) in Aliquat ${ }^{\circledR} 336 ;[\mathrm{In}]=5 \mathrm{~g} \mathrm{~L}^{-1},[\mathrm{HCl}]=0.5-12 \mathrm{M}$ & $396-447$ \\
\hline In(III) in Cyphos ${ }^{\circledR}$ IL 101; [In] $]=5 \mathrm{~g} \mathrm{~L}^{-1},\left[\mathrm{CaCl}_{2}\right]=0.25-6 \mathrm{M}$ & $386-404$ \\
\hline In(III) in Aliquat ${ }^{\circledR} 336 ;[\mathrm{In}]=5 \mathrm{~g} \mathrm{~L}^{-1},\left[\mathrm{CaCl}_{2}\right]=0.25-6 \mathrm{M}$ & $396-422$ \\
\hline$\left[\mathrm{InCl}_{4}\right]^{-}$in various solvents $\mathrm{s}^{\mathrm{a}}$ & $416-480$ \\
\hline$\left[\mathrm{InCl}_{5}\right]^{2-}$ in $\mathrm{CH}_{2} \mathrm{Cl}_{2}{ }^{\mathrm{b}}$ & $326^{b}$ \\
\hline$\left[\mathrm{InCl}_{6}\right]^{3-}$ in $\mathrm{CH}_{2} \mathrm{Cl}_{2}{ }^{\mathrm{b}}$ & $206^{b}$ \\
\hline
\end{tabular}

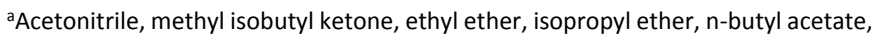
cyclohexanone, ethyl acetoacetate, dichloromethane, acetone, chloroform, tetrahydrofuran, methanol, water and water-acetone solutions. ${ }^{b}$ Chemical shifts assumed for the 'pure' penta- and hexacoordinate anions, based on the chemical shift of the ${ }^{115}$ In signal for various compositions. ${ }^{52}$ ionic liquid phase as tetrachloroindate(III) anions, confirming the EXAFS data. ${ }^{115}$ In NMR spectra of the ionic liquid phase after extraction using $\mathrm{CaCl}_{2}$ instead of $\mathrm{HCl}$ as a chloride source were also measured. The spectra as a function of the $\mathrm{CaCl}_{2}$ concentration $\left(\left[\mathrm{CaCl}_{2}\right]=0.25,0.5,1.5,3,4.5,6 \mathrm{M}\right.$; $\left.[\mathrm{In}]=5 \mathrm{~g} \mathrm{~L}^{-1}\right)$ for the Cyphos ${ }^{\circledR} \mathrm{IL} 101-\mathrm{InCl}_{3}$ and Aliquat ${ }^{\circledR} 336-\mathrm{InCl}_{3}$ system are shown in Fig. +S7. The chemical shifts found are shown in Table 3. Again, chemical shifts are observed corresponding to the tetrachloroindate(III) anion.

\section{Solvent extraction mechanism}

The aqueous phase exists as a series of indium(III) chloride complexes in acidic chloride media with a distinct distribution of the species $\left[\ln \left(\mathrm{H}_{2} \mathrm{O}\right)_{6}\right]^{3+},\left[\ln \left(\mathrm{H}_{2} \mathrm{O}\right)_{5} \mathrm{Cl}\right]^{2+},\left[\ln \left(\mathrm{H}_{2} \mathrm{O}\right)_{4} \mathrm{Cl}_{2}\right]^{+}$, $\ln \left(\mathrm{H}_{2} \mathrm{O}\right)_{3} \mathrm{Cl}_{3}, \quad\left[\ln \left(\mathrm{H}_{2} \mathrm{O}\right)_{2} \mathrm{Cl}_{4}\right]^{-}, \quad\left[\ln \left(\mathrm{H}_{2} \mathrm{O}\right) \mathrm{Cl}_{5}\right]^{2-}$ and $\left.[\operatorname{lnCl}]_{6}\right]^{3-}$, depending on chloride concentrations. Fig. 7 shows the average number of chlorides, $\bar{n}$, in the indium complex $\left[\ln \left(\mathrm{H}_{2} \mathrm{O}\right)_{6-n} \mathrm{Cl} n\right]^{3-n}$ as a function of the $\mathrm{HCl}$ concentration in an aqueous solution. The highest concentration of $\left[\ln \left(\mathrm{H}_{2} \mathrm{O}\right)_{4} \mathrm{Cl}_{2}\right]^{+}$species is found at approximately $0.5 \mathrm{M} \mathrm{HCl}$, while the $\ln \left(\mathrm{H}_{2} \mathrm{O}\right)_{3} \mathrm{Cl}_{3}$ species are more abundant at approximately $4.5 \mathrm{M} \mathrm{HCl}$. The $\left[\ln \left(\mathrm{H}_{2} \mathrm{O}\right)_{2} \mathrm{Cl}_{4}\right]^{-}$and $\left[\ln \left(\mathrm{H}_{2} \mathrm{O}\right) \mathrm{Cl}_{5}\right]^{2-}$ species are most concentrated at 8 and $12 \mathrm{M} \mathrm{HCl}$, respectively. The positively and negatively charged chloroindate(III) complexes, $\left[\ln \left(\mathrm{H}_{2} \mathrm{O}\right)_{6}\right]^{3+}, \quad\left[\ln \left(\mathrm{H}_{2} \mathrm{O}\right)_{5} \mathrm{Cl}\right]^{2+}$, $\left[\ln \left(\mathrm{H}_{2} \mathrm{O}\right)_{4} \mathrm{Cl}_{2}\right]^{+}\left[\ln \left(\mathrm{H}_{2} \mathrm{O}\right)_{2} \mathrm{Cl}_{4}\right]^{-}, \quad\left[\ln \left(\mathrm{H}_{2} \mathrm{O}\right) \mathrm{Cl}_{5}\right]^{2-}$ and $\left[\ln \mathrm{Il}_{6}\right]^{3-}$, are strongly hydrated in comparison to the neutral $\ln \left(\mathrm{H}_{2} \mathrm{O}\right)_{3} \mathrm{Cl}_{3}$.

Although a series of indium(III) chloride complexes are in equilibrium with each other in the aqueous phase, EXAFS and ${ }^{115}$ In NMR measurements confirmed that $\left[\mathrm{InCl}_{4}\right]^{-}$is the only type of complex formed in the ionic liquid phase. Extraction of the $\left[\ln \left(\mathrm{H}_{2} \mathrm{O}\right)_{2} \mathrm{Cl}_{4}\right]^{-}$to the ionic liquid phase through anion exchange would correspond with the transfer of one chloride ion and two coordinating water molecules into the aqueous phase. It seems more likely that the complex extracted to the ionic liquid phase is $\ln \left(\mathrm{H}_{2} \mathrm{O}\right)_{3} \mathrm{Cl}_{3}$, which is less hydrated than $\left[\ln \left(\mathrm{H}_{2} \mathrm{O}\right)_{2} \mathrm{Cl}_{4}\right]^{-}$, and avoiding the transfer of the chloride ion to the aqueous phase. The $\ln \left(\mathrm{H}_{2} \mathrm{O}\right)_{3} \mathrm{Cl}_{3}$ complex is subsequently converted into [ $\left.\mathrm{InCl}\right]_{4}^{-}$ by complexation with another $\mathrm{Cl}$ anion from the ionic liquid phase. The same observations were made regarding the

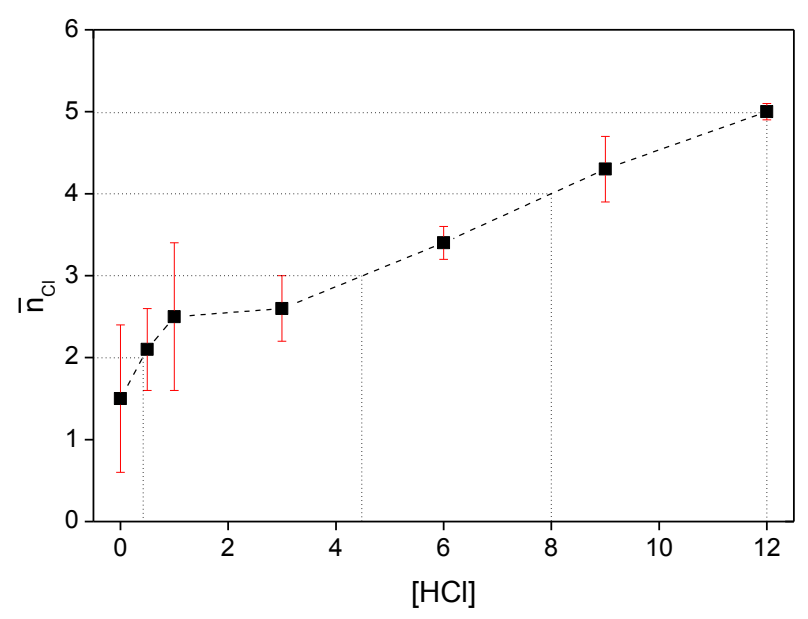

Fig. 7 Average number of chlorides $\left(\bar{n}_{\mathrm{Cl}}\right)$ in the indium complex $\left[\ln \left(\mathrm{H}_{2} \mathrm{O}\right)_{6-n} \mathrm{Cl}_{n}\right]^{3-n}$ as a function of the $[\mathrm{HCl}]$ in an aqueous solution. 
exchange of salt anions in the aqueous phase with the anions of the ionic liquid in contact with it. ${ }^{65}$ The occurrence of this kind of anion exchange can be predicted based on the Hofmeister series. Anion exchange with strongly hydrated species is more difficult than with weakly hydrated ones. Moreover, the tetrachloroindate(III) species in the aqueous phase is hydrated by 2 water molecules, which is not the case for the indium species in the organic phase. Therefore, we believe that writing the extraction as an anion exchange mechanism might be wrong from a coordination point of view.

Our hypothesis is confirmed by monitoring the distribution ratios of indium(III) $\left(D_{\text {In }}\right)$ as a function of the $\mathrm{HCl}$ concentration for the $\mathrm{HCl}-$ Cyphos ${ }^{\circledR}$ IL 101 and $\mathrm{HCl}-$ Aliquat ${ }^{\circledR} 336$ systems (Fig. 2). The bell-shaped curve of the distribution ratio was tentatively attributed to a change in speciation or stability of the indium complexes in the aqueous and/or in the ionic liquid phase. It was already determined by EXAFS and ${ }^{115}$ In NMR that the speciation in the ionic liquid phase did not change as a function of the $\mathrm{HCl}$ concentration. Hence, the bell-shaped curve is solely attributed to the change in speciation or stability of the indium complexes in the aqueous phase. The maximum $D_{\ln }$ is situated at a $\mathrm{HCl}$ concentration of $5 \mathrm{M}$ where the neutral $\ln \left(\mathrm{H}_{2} \mathrm{O}\right)_{3} \mathrm{Cl}_{3}$ complex is dominantly present in the aqueous phase, confirming the proposed extraction mechanism. The occurring reactions are presented in eqs. 7-9:

$$
\begin{gathered}
\left(\left[\operatorname{In}\left(\mathrm{H}_{2} \mathbf{O}\right)_{6}\right]^{3+}\right)_{\mathrm{Aq}} \rightleftharpoons\left(\left[\operatorname{In}\left(\mathrm{H}_{2} \mathbf{O}\right)_{6-\mathrm{n}} \mathrm{Cl}_{\mathbf{n}}\right]^{3-n}\right)_{\mathrm{Aq}}(\mathrm{n}=1-6) \\
\left(\mathrm{InCl}_{3}\left(\mathrm{H}_{2} \mathbf{O}\right)_{3}\right)_{\mathrm{Aq}} \rightleftharpoons\left(\mathrm{InCl}_{3}\left(\mathrm{H}_{2} \mathbf{O}\right)_{3}\right)_{\mathrm{IL}} \\
\left(\mathrm{InCl}_{3}\left(\mathrm{H}_{\mathbf{2}} \mathbf{O}\right)_{3}\right)_{\mathrm{IL}}+\left(\left[\mathrm{IL}_{\mathrm{cat}}\right][\mathrm{Cl}]\right)_{\mathrm{IL}} \rightleftharpoons \\
\left(\left[\mathrm{IL}_{\mathrm{cat}}\right]\left[\mathrm{InCl}_{4}\right]\right)_{\mathrm{IL}}+\left(3 \mathrm{H}_{2} \mathbf{O}\right)_{\mathrm{Aq}}
\end{gathered}
$$

In literature, it is often claimed that the extraction mechanism with Cyphos ${ }^{\circledR}$ IL 101 and Aliquat ${ }^{\circledR} 336$ is based on anion exchange. ${ }^{60,66-70}$ During this process, metal complex anions move from aqueous phase to organic phase, while anions in the organic phase transfer from organic phase into aqueous phase to achieve a charge balance in each phase. Based on our research, it is concluded that a neutral $\ln \left(\mathrm{H}_{2} \mathrm{O}\right)_{3} \mathrm{Cl}_{3}$ complex is extracted from the aqueous phase to the organic phase, and is subsequently converted into $\left[\mathrm{InCl}_{4}\right]^{\text {. The cationic }}$ species are too hydrophilic to be extracted and the highly negative charged complexes are strongly hydrated. We do not exclude that both the proposed and anion exchange mechanisms are at play.

\section{Conclusions}

Knowledge of the metal extraction mechanism and the metal species involved allows optimization of extraction systems. In order to determine the extraction mechanism of indium(III) from $\mathrm{HCl}$ solution with the undiluted ionic liquids Cyphos $\AA$ IL 101 and Aliquat ${ }^{\circledR} 336$ in combination with the indium(III) speciation in both phases, several techniques were applied. In aqueous $\mathrm{HCl}$ solutions (0-12 M), indium(III) exists as octahedral mixed complexes, $\left[\ln \left(\mathrm{H}_{2} \mathrm{O}\right)_{6-n} \mathrm{Cl}_{n}\right]^{3-n}(0 \leq n \leq 6)$. EXAFS and ${ }^{115}$ In NMR were used to characterize the dominant species in solution. Depending on the $\mathrm{HCl}$ concentration, the following indium complexes are dominant: $\left[\ln \left(\mathrm{H}_{2} \mathrm{O}\right)_{2} \mathrm{Cl}_{2}\right]^{+}(0-1 \mathrm{M} \mathrm{HCl})$, $\left[\ln \left(\mathrm{H}_{2} \mathrm{O}\right)_{3} \mathrm{Cl}_{3}\right](1-6 \mathrm{M} \mathrm{HCl}),\left[\ln \left(\mathrm{H}_{2} \mathrm{O}\right)_{2} \mathrm{Cl}_{4}\right]^{-}(6-10 \mathrm{M} \mathrm{HCl})$ and $\left[\ln \left(\mathrm{H}_{2} \mathrm{O}\right) \mathrm{Cl}_{5}\right]^{2-}(10-12 \mathrm{M} \mathrm{HCl})$. The stoichiometry of the extracted complexes was estimated using viscosity and maximal loading studies, and confirmed by ${ }^{115}$ In NMR and EXAFS. These techniques revealed that indium(III) is present as a tetrahedral $\left[\mathrm{InCl}_{4}\right]^{-}$complex in the ionic liquids independent of the $\mathrm{HCl}$ concentration in the aqueous phase. The aqueous phase exists in the form of a series of octahedral mixed indium(III) chloride complexes in acidic chloride media with a distinct distribution of the species $\left[\ln \left(\mathrm{H}_{2} \mathrm{O}\right)_{6}\right]^{3+},\left[\ln \left(\mathrm{H}_{2} \mathrm{O}\right)_{5} \mathrm{Cl}\right]^{2+},\left[\ln \left(\mathrm{H}_{2} \mathrm{O}\right)_{4} \mathrm{Cl}_{2}\right]^{+}$, $\ln \left(\mathrm{H}_{2} \mathrm{O}\right)_{3} \mathrm{Cl}_{3}, \quad\left[\ln \left(\mathrm{H}_{2} \mathrm{O}\right)_{2} \mathrm{Cl}_{4}\right]^{-}, \quad\left[\ln \left(\mathrm{H}_{2} \mathrm{O}\right) \mathrm{Cl}_{5}\right]^{2-}$ and $\left.[\operatorname{lnCl}]_{6}\right]^{3-}$, depending on the $\mathrm{HCl}$ concentration. The charged cationic and anionic species are strongly hydrated and too hydrophilic to be extracted. Consequently, indium(III) can be extracted as a neutral complex, $\ln \left(\mathrm{H}_{2} \mathrm{O}\right)_{3} \mathrm{Cl}_{3}$. The $\ln \left(\mathrm{H}_{2} \mathrm{O}\right)_{3} \mathrm{Cl}_{3}$ complex is most likely extracted to the ionic liquid phase, as a consequence of being the least hydrated, thereby avoiding the transfer of a chloride ion to the aqueous phase. This hypothesis was confirmed by the presence of a maximum in the distribution ratio of indium(III) at a $\mathrm{HCl}$ concentration of $5 \mathrm{M}$. At this concentration, the $\ln \left(\mathrm{H}_{2} \mathrm{O}\right)_{3} \mathrm{Cl}_{3}$ complex is dominantly present in the aqueous phase.

\section{Acknowledgements}

This research was supported by the Flemish Institute for the Promotion of Innovation by Science and Technology (IWT Vlaanderen) via a Baekeland PhD fellowship to Clio Deferm (IWT 130305) and by the Umicore Group Research \& Development. The authors also wish to thank Karel Duerinckx for the NMR measurements, DUBBLE for funding the EXAFS measurements and Jeroen Sniekers for doing the night shifts at the beamline.

\section{Notes and references}

1 Report on critical raw materials for the EU, http://ec.europa.eu/growth/sectors/raw-materials/specificinterest/critical/index_en.htm (accessed June 2016).

2 U. Scwarz-Schampera and P. M. Herzig, Indium: Geology, Mineralogy, and Economics, Springer Verlag, New York, 2002.

3 Historical statistics for mineral and material commodities in the United States: U.S. Geological Survey Data Series 140, http://minerals.usgs.gov/ds/2005/140/ (accessed June 2016).

4 A.M. Alfantazi, A.M. and R.R. Moskalyk, Miner. Eng., 2003, 16, 687-694.

5 N. Felix, in Ullmann's Encyclopedia of Industrial Chemistry, ed. F. Ullmann, WILEY-VCH, Weinheim, 2012, Vol. 19, pp. 65-74.

6 Critical Materials Profiles, http://ec.europa.eu/growth/sectors/raw-materials/specificinterest/critical/index_en.htm (accessed June 2016).

7 A. P. Paiva, Sep. Sci. Technol., 2001, 36, 1395-1419.

8 J. G. Huddleston, H. D. Willauer, R. P. Swatloski, A. E. Visser and R. D. Rogers, Chem. Commun., 1998, 1765-1766.

9 F. Kubota and M. Goto, Solvent Extr. Res. Dev., Jpn., 2006, 13, 23-36.

10 M. L. Dietz, Sep. Sci. Technol. 2006, 41, 2047-2063. 
11 N. V. Plechkova and K. R. Seddon, Chem. Soc. Rev., 2008, 37, 123-150.

12 T. Welton, Chem. Rev., 1999, 99, 2071-2083.

13 R. D. Rogers and K. R. Seddon, Science, 2003, 302, 792-793.

14 D. Coleman and N. Gathergood, Chem. Soc. Rev., 2010, 39, 600-637.

15 M. Petkovic, K. R. Seddon, L. P. N. Rebelo and C. Silva Pereira, Chem. Soc. Rev., 2011, 40, 1383-1403.

16 S.-K. Mikkola, A. Robciuc, J. Lokajová, A. J. Holding, M. Lämmerhofer, I. Kilpeläinen, J. M. Holopainen, A. W. T. King and S. K. Wiedmer, Environ. Sci. Technol., 2015, 49, 18701878.

17 J. Park, Y. Jung, P. Kusumah, J. Lee, K. Kwon and C. K. Lee, Int. J. Mol. Sci., 2014, 15, 15320-15343.

18 D. Parmentier, S. J. Metz and M. C. Kroon, Green Chem., 2013, 15, 205-209.

19 N. Papaiconomou, G. Vite, N. Goujon, J. M. Leveque and I. Billard, Green Chem., 2012, 14, 2050-2056.

20 N. Papaiconomou, J.-M. Lee, J. Salminen, M. von Stosch and J. M. Prausnitz, Ind. Eng. Chem. Res., 2008, 47, 5080-5086.

21 I. Billard, A. Ouadi and C. Gaillard, Anal. Bioanal. Chem., 2011, 400, 1555-1566.

22 J. G. Huddleston, A. E. Visser, W. M. Reichert, H. D. Willauer, G. A. Broker and R. D. Rogers, Green Chem., 2001, 3, 156-164.

23 P. G. Rickert, D. C. Stepinski, D. J. Rausch, R. M. Bergeron, S. Jakab and M. L. Dietz, Talanta, 2007, 72, 315-320.

24 R. P. Swatloski, J. D. Holbrey and R. D. Rogers, Green Chem. 2003, 5, 361-363.

25 R. K. Mishra, P. C. Rout, K. Sarangi and K. C. Nathsarma, Hydrometallurgy, 2011, 108, 93-99.

26 F. d. M. Fábrega and M. B. Mansur, Hydrometallurgy, 2007, 87, 83-90

27 J. Castillo, M. T. Coll, A. Fortuny, P. N. Donoso, R. Sepúlveda and A. María Sastre, Hydrometallurgy, 2014, 141, 89-96.

28 M. Regel-Rosocka, Ł. Nowak and M. Wiśniewski, Sep. Purif. Technol., 2012, 97, 158-163.

29 A. Cieszynska and M. Wiśniewski, Sep. Purif. Technol., 2011, 80, 385-389.

30 M. Regel-Rosocka and M. Wiśniewski, Hydrometallurgy, 2011, 110, 85-90.

31 D. Kogelnig, A. Stojanovic, F. Jirsa, W. Körner, R. Krachler and B. K. Keppler, Sep. Purif. Technol., 2010, 72, 56-60.

32 P. Rybka and M. Regel-Rosock, Sep. Sci. Technol., 2012, 47, 1296-1302.

33 L. Svecova, N. Papaiconomou and I. Billard, Dalton Trans., 2016, 45, 15162-15169.

34 M. P. Jensen, J. Neuefeind, J. V. Beitz, S. Skanthakumar and L. Soderholm, J. Am. Chem. Soc., 2003, 125, 15466-15473.

35 M. L. Dietz, J. A. Dzielawa, I. Laszak, B. A. Young and M. P. Jensen, Green Chem., 2003, 5, 682-685.

36 C. H. C. Janssen, A. Sanchez, G. J. Witkamp and M. N. Kobrak, Chem. Phys. Chem., 2013, 14, 3806-3813.

37 A. Messadi, A. Mohamadou, S. Boudesocque, L. Dupont and E. Guillon, Sep. Purif. Technol., 2013, 107, 172-178.

38 H. Narita, M. Tanaka, H. Shiwaku, Y. Okamoto, S. Suzuki, A. Ikeda-Ohnob and T. Yaitab, Dalton Trans., 2014, 43, 1630.

39 C. Deferm, M. Van de Voorde, J. Luyten, H. Oosterhof, J. Fransaer and K. Binnemans, Green Chem., 2016, 18, 41164127.

40 K. V. Klementev, Nucl. Instrum. Methods Phys. Res., Sect. A, 2000, 448, 299-301.

41 M. Newville,J. Synchrotron Radiat., 2001,8,96-100.

42 D. G. Tuck, Pure Appl. Chem., 1983, 55, 1477-1528.

43 S.A. Wood and I.M. Samson, Ore Geology Reviews, 2006, 28 , 57-102.

44 T. Jarv, J.T. Bulmer and D.E. Irish, J. Phys. Chem., 1977, 81 649-656.

45 M.P. Hasson and R.A. Plane, Inorg. Chem., 1969, 8, 746-750.
46 J.A. Schufle, M.F. Stubbs, R.E. Witman, J. Am. Chem. Soc., 1951, 73, 1013-1015.

47 T.M. Seward, C.M.B. Henderson and J.M. Charnock, Chemical Geology, 2000, 167, 117- 127.

48 J.W. Akitt, in Multinuclear NMR, ed. J. Mason, Plenum Press, New York, 1987, chapter 9, 259-287.

49 J.P. André and H.R. Mäcke, J. Inorg. Biochem., 2003, 97, 315323.

50 M. A. Malyarick and S.P. Petrosyants, Inorg. Chem., 1993, 32 2265-2268.

51 A. Fratiello, D.D. Davis, S. Peak, R.E. Schuster, Inorg. Chem. 1971, 10, 1627-1632.

52 B.R. McGarvey, C.O. Trudell, D.G. Tuck and L. Victoriano, Inorg. Chem., 1980, 19, 3432-3436.

53 T. H. Cannon and R. E. Richards, Trans. Faraday Soc., 1966, 62 1378-1387.

54 H. Haraguchi, K. Fuwa and S. Fujiwara, J. Phys. Chem., 1973, 77, 1497-1500.

55 R. Banda, T.H. Nguyen and M.S. Lee, Chem. Process Eng., 2013, 34, 153-163.

56 T. Hirai and I. Komasawa, J. Chem. Eng. Jpn., 1991, 24, 58-62.

57 T. Sato, H. Watanabe and S. Kikuchi, J. Chem. Technol. Biotechnol., 1975, 25, 63-72.

58 T. Vander Hoogerstraete and K. Binnemans, Green Chem. 2014, 16, 1594-1606.

59 S. Wellens, R. Goovaerts, C. Möller, J. Luyten, B. Thijs and K. Binnemans, Green Chem., 2013, 15, 3160-3164.

60 T. Vander Hoogerstraete, S. Wellens, K. Verachtert and K. Binnemans, Green Chem., 2013, 15, 919-927.

61 A. Rout and K. Binnemans, Dalton Trans., 2014, 43, 31863195.

62 D.C. Apperley, C. Hardacre, P. Licence, R.W. Murphy, N.V. Plechkova, K.R. Seddon, G. Srinivasan, M. Swadźba-Kwaśny and I.J. Villar-Garcia, Dalton Trans., 2010, 39, 8679-8687.

63 C. Hardacre, R.W. Murphy, K.R. Seddon, G. Srinivasan and M. Swadzba-Kwasny, Aus. J. Chem., 2010, 63, 845-848.

64 J. Estager, A.A. Oliferenko, K.R. Seddon and M. SwadźbaKwaśny, Dalton Trans., 2010, 39, 11375-11382.

65 D. Dupont, D. Depuydt and K. Binnemans, J. Phys. Chem. B 2015, 119, 6747-6757.

66 P. Rybka and M. Regel-Rosocka, Sep. Sci. Technol., 2012, 47, 1296-1302.

67 F.M. Fábrega and M.B. Mansur, Hydrometallurgy, 2007, 87, 83-90.

68 R.K. Mishra, P.C. Rout, K. Sarangi and K.C. Nathsarma, Hydrometallurgy, 2011, 108, 93-99.

69 M. Regel-Rosocka and M. Wisniewski, Hydrometallurgy, 2011 $110,85-90$.

70 S. Wellens, B. Thijs and K. Binnemans, Green Chem., 2012, 14 $1657-1665$ 